\title{
Condition factor variations over time and trophic position among four species of Characidae from Amazonian floodplain lakes: effects of an anomalous drought
}

\author{
I. A. Tribuzy-Neto ${ }^{a}$, K. G. Conceição ${ }^{a}$, F. K. Siqueira-Souza ${ }^{a}$, L. E. Hurd ${ }^{b}$ and C. E. C. Freitas ${ }^{a *}$ \\ aDepartment of Fisheries Sciences, Universidade Federal do Amazonas - UFAM, Campus Universitário, \\ Av. General Rodrigo Otávio Jordão Ramos, 6200, CEP 69077-000, Manaus, AM, Brazil

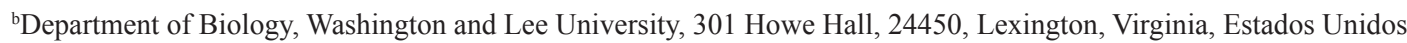 \\ *e-mail: cefreitas@ufam.edu.br
}

Received: July 7, 2016 - Accepted: November 23, 2016 - Distributed: May 31, 2018

(With 5 figures)

\begin{abstract}
The effects of extreme droughts on freshwater fish remain unknown worldwide. In this paper, we estimated the condition factor, a measure of relative fitness based on the relationship of body weight to length, in four fish species representing two trophic levels (omnivores and piscivores) from Amazonian floodplain lakes for three consecutive years: 2004, 2005 (an anomalous drought year), and 2006. The two omnivores, Colossoma macropomum and Mylossoma duriventre, exhibited trends consistent with their life cycles in 2004 and 2006: high values during the hydrologic seasons of high water, receding water, and low water, with a drop following reproduction following the onset of rising water. However during the drought year of 2005 the condition factor was much lower than normal during receding and low water seasons, probably as a result of an abnormal reduction in resource availability in a reduced habitat. The two piscivorous piranhas, Serrasalmus spilopleura and S. elongatus, maintained relatively stable values of condition factor over the hydrologic cycles of all three years, with no apparent effect of the drought, probably because the reduction in habitat is counterbalanced by the resulting increase in relative prey density. We suggest that if predictions of increasing drought in the Amazon are correct, predatory species may benefit, at least in the short run, while omnivores may be negatively affected.
\end{abstract}

Keywords: fish fitness, environmental effects, Colossoma macropomum, Mylossoma duriventre, Serrasalmus spilopleura, Serrasalmus elongatus.

\section{Variações do fator de condição de quatro espécies de Characidae de lagos de várzea da Amazônia como função do tempo e da posição trófica: efeitos de uma seca anômala}

\begin{abstract}
Resumo
Os efeitos de secas extremas sobre peixes de água doce ainda é globalmente desconhecido. Neste artigo, nós estimamos o fator de condição, uma medida relativa de bem estar baseada na relação entre e peso do corpo e o comprimento, em quatro espécies de peixes de lagos da Amazônia, pertencentes a dois níveis tróficos (onívoros e carnívoros), capturadas durante três anos consecutivos: 2004, 2005 (quando ocorreu uma seca anômala) e 2006. As duas espécies onívoras, Colossoma macropomum e Mylossoma duriventre exibiram tendências consistentes com seu ciclo de vida nos anos de 2004 e 2006: valores mais altos na cheia, vazante e seca, seguida por uma queda na enchente que coincide com a estação reprodutiva. No entanto, o fator de condição foi muito menor durante a seca e a enchente em 2005, provavelmente devido a redução anormal na disponibilidade de recursos em um habitat reduzido. As duas espécies piscívoras, as piranhas Serrasalmus spilopleura e S. elongatus, mantiveram relativa estabilidade nas estimativas do fator d condição, ao longo do ciclo hidrológico dos três anos, sem efeito aparente da seca extrema, provavelmente porque a redução do habitat foi contrabalanceada pelo aumento na densidade de presas. Caso as predições de aumento de frequência de secas extremas venha a se confirmar, acreditamos que espécies predadoras poderão ser beneficiadas, ao menos no curto prazo, enquanto as onívoras serão negativamente afetadas.
\end{abstract}

Palavras-chave: bem estar, efeitos ambientais, Colossoma macropomum, Mylossoma duriventre, Serrasalmus spilopleura, Serrasalmus elongatus. 


\section{Introduction}

The aquatic environment of the Amazonian floodplains in Brazil contains thousands of lakes and associated wetlands that are interconnected to varying degrees, forming a huge and complex drainage network. These environments are highly dynamic, with an annual hydrologic cycle known as the flood pulse (Junk et al., 1989). The flood pulse is the main driving force structuring the aquatic biota of the floodplain ecosystem along the Amazon River (Junk et al., 1989; Sousa and Freitas, 2008; Hurd et al., 2016). In general, the seasonal flood reaches its peak in June and July, and its lowest point in October and November (Bittencourt and Amadio, 2007). This phenomenon promotes dramatic changes in the floodplain landscape, with alternation between terrestrial and aquatic periods of several months duration.

In general, the period of seasonal flooding is advantageous for fish, since there is an expansion of the aquatic environment, improving the accessibility of habitat and food sources (Goulding, 1980). At such time lake fish can enter the adjacent flooded forest and feed on fruits, seeds, insects, and terrestrial invertebrates (Fernandes, 1997; Claro-Junior et al., 2004; Mérona and Rankin-de-Mérona, 2004; Noveras et al., 2010; Correa and Winemiller, 2014). In contrast, lakes diminish in depth and area during the low-water season, with a consequent decline in habitat and food availability.

Over evolutionary time, these strong but predictable changes in the physical environment have promoted a variety of physiological, morphological and behavioral adaptations among fish species (Saint-Paul and Soares, 1987; Almeida-Val and Val, 1990; Val et al., 1998). However, these floodplains are currently under increasing threat from climate change and resultant modifications to the hydrologic cycle (Melack and Coe, 2013). The intra-annual hydrologic cycle caused by the normal flood pulse is exacerbated by the warming sea-surface temperatures in the Tropical Atlantic, as well as by events such as the El Nino-Southern Oscillation phenomenon (Marengo et al., 2013), which in turn can have dramatic impacts on aquatic organisms in the Amazon Basin (Freitas et al., 2013). These relatively recent changes could well be outside the adaptive range of many species. Recent studies indicate that increasing the frequency of extreme events of flood and drought could disrupt the ecological and evolutionary balance of this ecosystem with unpredictable consequences (Freitas et al., 2013). Fish species at risk may include some that are important protein sources for residents of the Amazon Basin, as well as those that may be important to maintaining the ecological integrity of the system.

Two species that are very important constituents of Amazonian fisheries are Colossoma macropomum (tambaqui) and Mylossoma duriventre (pacú-manteiga). Both of these are omnivorous species (Araújo-Lima and Goulding, 1998; Claro-Junior et al., 2004; Soares et al., 2007). Adults of both species undergo annual migrations during rising water from the lakes to the rivers and them upriver for breeding (Goulding and Carvalho, 1982; Lima and Araujo-Lima, 2004; Granado-Lorencio et al., 2005). After breeding, they move to floodplain areas for shelter and feeding in the flooded forests (Fernandes, 1997; Saint-Paul et al., 2000; Soares et al., 2007; Noveras et al., 2010). Colossoma macropomum is the second largest scaled fish in the Amazon basin, and its populations are already overexploited in some areas (Isaac and Ruffino, 1996; Freitas et al., 2007; Campos et al., 2015). Mylossoma duriventre is a smaller-bodied fish that forms large schools during reproductive migrations (Granado-Lorencio et al., 2005). At such times this species is heavily fished with purse seines known locally as redinha.

In contrast, two species in the family Serrasalmidae that are not commercially exploited, probably due in part to their large number of intra-muscular bones, are Serrasalmus spilopleura and S. elongatus. These piranha species occupy a different trophic position than the other two species, being piscivorous, and are both widespread and very abundant in Amazonian floodplain lakes.

Ficke et al. (2007) proposed that environmental changes would first result in detectable effects at the organism level, and next at the population level. Therefore, we measured a component of ecological fitness known as the condition factor, estimated by the body weight-length relationship, as a welfare index for all four of the above-described Characid species over three consecutive years to test two null hypothesis: (1) there were no inter-annual changes in the fish fitness (comparison among years) and (2) there were no intra-annual changes in the fish fitness (comparison among seasons of the hydrologic cycle). Finally, we compared the dynamics of this index between the two trophic positions represented by the four studied species.

\section{Material and Methods}

\subsection{Study area}

The study area comprised eight lakes situated along $400 \mathrm{~km}$ of the floodplain adjacent to the Solimões River: Baixio, Preto, Iauara, Ananá, Maracá, Araçá, Poraquê and Aruã (Figure 1). All these lakes normally remain connected to the main river during most of the year, typical of permanent floodplain lakes. There was an extreme drought in this region during 2005 as a result of combined effects of El Nino Southern Oscillation - ENSO and abnormally elevated sea surface temperatures in the southern area of the North Atlantic (Marengo, 1992; Marengo et al., 2008). This drought affected both terrestrial (Phillips et al., 2009) and aquatic (Freitas et al., 2013) ecosystems in this region. We therefore have data from our fish assemblages immediately before, during, and following the drought.

\subsection{Sampling Procedure}

We sampled C. macropomum, M. duriventre, S. spilopleura and S. elongatus in these lakes in 2004, 2005, and 2006 during the middle of all four seasons of the hydrologic cycle: rising water, high water, receding water, and low water. The fish were collected from each 


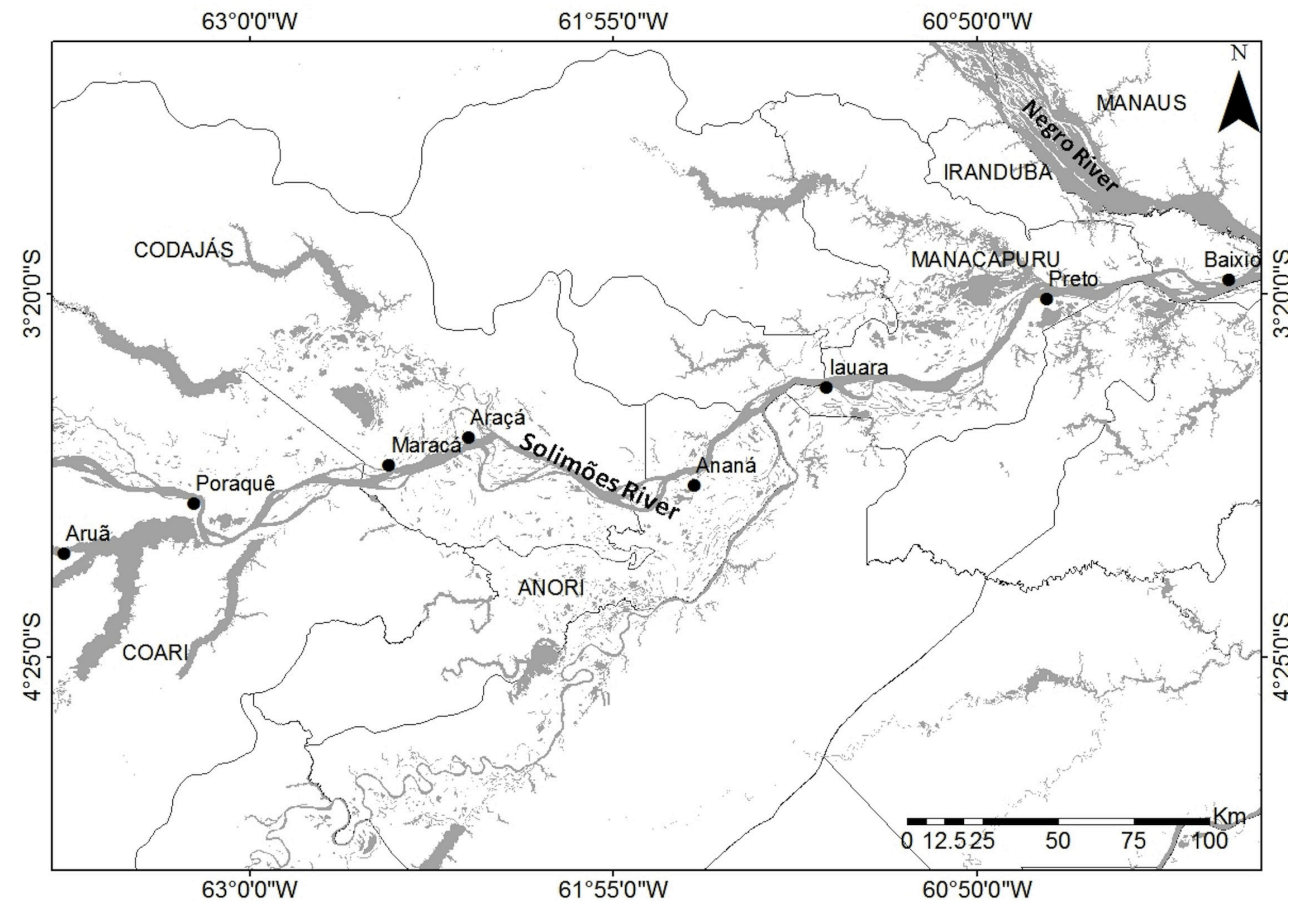

Figure 1. Map of the study area highlighting the Solimões River and the eight floodplain lakes where we sampled fish.

lake with eight gillnets of standardized dimensions (20 $\mathrm{m}$ long and $2 \mathrm{~m}$ high) and different mesh sizes: $30,40,50,60,70,80,90$, and $100 \mathrm{~mm}$ between opposite knots. The nets were placed at sunrise, during the hour 5-6am, remained in place for 12 hours, and removed at sundown, between 6-7pm. Collected fish were identified, measured (standard length, $\mathrm{cm}$ ) and weighed (total body mass, g) immediately after the catch. Any species that were difficult to identify on site were preserved in $10 \%$ formalin and transported to the Laboratory of Fishing Ecology at the Federal University of Amazonas (UFAM), where identification was made with expert support.

\subsection{Data analysis}

The parameters of the weight-length relationship were determined for all four species by non-linear estimation, employing the Levenberg-Marquardt algorithm (Myers,

1990). The relative condition factor (kn) was estimated by the equation $k n=$ Wobs $/$ West $($ Cren, 1951), were Wobs is the measured body mass of each fish and West is the estimated weight calculated for each length using the estimated weight-length relationship. The $\log (\ln )$ of the mean of the relative condition factor $(\mathrm{kn})$ was estimated on the grouped data for each hydrological season and year. After a graphic check for violations of the linear conditions, a two-way Analysis of Variance was employed to test the following null hypotheses: $\mathrm{H}_{0} 1$ : there were no effects of the year on the condition factor; $\mathrm{H}_{0} 2$ : there were no effects of the hydrologic season on the condition factor; and, $\mathrm{H}_{0} 3$ : there were no effects of interactions between year and the hydrological season on the condition factor. A Tukey's post hoc test was employed whenever a null hypothesis was rejected. All statistical procedures were performed using the software Statistica 9.0 (Statsoft Inc, 2009) with a confidence level of 0.05 .

\section{Results}

We collected 1,318 fish over the three years of the study. The piranha S. spilopleura was more than twice as abundant as each the other three species (Table 1). The composite data in Table 1 show that S. spilopleura was also the smallest bodied fish, while the omnivore C. macropomum was the largest. However, the composite data do not show the variations that occurred in the weight-length condition factor index. The estimated weight-length relationship exhibited a good fit for all species (Table 2), besides C. macropomum and M. duriventre were represented mainly by small individuals.

Both of the omnivorous species and one of the piranhas (S. spilopleura) exhibited significant differences in the condition factor by year, by season of the hydrologic cycle and were detected interaction effects of year and season of the hydrologic cycle (Table 3). For C. macropomum, this interaction effect can be identified with the anomalous drought of 2005. In general, the relative condition factor of C. macropomum was highest during the high and receding water seasons of all three years, showing intermediary values for rising water seasons of 2004 and 2005 and low water seasons of 2004 and 2006. The lowest estimates were observed during the rising water of 2006 
Table 1. Number of sampled fish, minimum ( $\min )$, maximum (max), mean $(\bar{x})$ and standard deviation $(s d)$ of length and weight of the four characids.

\begin{tabular}{|c|c|c|c|c|c|}
\hline \multirow{2}{*}{ Species } & \multirow{2}{*}{ n } & \multicolumn{2}{|c|}{ Length (cm) } & \multicolumn{2}{|c|}{ Weight (g) } \\
\hline & & $\bar{x} \pm \mathbf{s d}$ & $\min -\max$ & $\bar{x} \pm \mathbf{s d}$ & $\min -\max$ \\
\hline Colossoma macropomum & 255 & $19.5 \pm 3.9$ & $10-36$ & $299.6 \pm 196.1$ & $40-1560$ \\
\hline Mylossoma duriventre & 254 & $13.1 \pm 2.6$ & $5.5-22$ & $111.0 \pm 73.0$ & $5-470$ \\
\hline Serrasalmus spilopleura & 557 & $11.6 \pm 3.1$ & $5.5-20$ & $73.9 \pm 48.1$ & $8-210$ \\
\hline Serrasalmus elongatus & 252 & $15.0 \pm 2.8$ & $6.0-28$ & $83.0 \pm 41.8$ & $10-295$ \\
\hline
\end{tabular}

Table 2. Summary of length-weight relationships for the four floodplain lake characids.

\begin{tabular}{lcc}
\hline \multicolumn{1}{c}{ Species } & Model & $\mathbf{R}^{2}$ \\
\hline Colossoma macropomum & $W=0.0716 L^{2.771}$ & 0.9207 \\
Mylossoma duriventre & $W=0.0429 L^{3.004}$ & 0.9597 \\
Serrasalmus spilopleura & $W=0.0698 L^{2.802}$ & 0.9301 \\
Serrasalmus elongatus & $W=0.0533 L^{2.720}$ & 0.8701 \\
\hline
\end{tabular}

Table 3. Summary of two-way ANOVA results applied to compare the condition factor of Colossoma macropomum, Mylossoma duriventre, Serrasalmus spilopleura and S. elongatus by year and season of the hydrological cycle.

\begin{tabular}{|c|c|c|c|c|c|c|c|c|c|c|c|c|}
\hline \multirow{2}{*}{$\begin{array}{l}\text { Source of } \\
\text { Variation }\end{array}$} & \multicolumn{3}{|c|}{$\begin{array}{c}\text { Colossoma } \\
\text { macropomum }\end{array}$} & \multicolumn{3}{|c|}{$\begin{array}{l}\text { Mylossoma } \\
\text { duriventre }\end{array}$} & \multicolumn{3}{|c|}{$\begin{array}{c}\text { Serrasalmus } \\
\text { spilopleura }\end{array}$} & \multicolumn{3}{|c|}{$\begin{array}{c}\text { Serrasalmus } \\
\text { elongatus }\end{array}$} \\
\hline & df & $\mathbf{F}$ & p & df & $\mathbf{F}$ & $\mathbf{p}$ & df & $\mathbf{F}$ & $\mathbf{p}$ & df & $\mathbf{F}$ & p \\
\hline Year & 2 & 13.81 & $<0.001$ & 2 & 48.86 & $<0.001$ & 2 & 13.89 & $<0.001$ & 2 & 0.56 & 0.569 \\
\hline Season & 3 & 38.74 & $<0.001$ & 3 & 31.75 & $<0.001$ & 3 & 6.54 & $<0.001$ & 3 & 1.92 & 0.127 \\
\hline Year*Season & 6 & 34.53 & $<0.001$ & 6 & 17.69 & $<0.001$ & 6 & 2.17 & $<0.001$ & 6 & 0.99 & 0.433 \\
\hline Error & 243 & & & 242 & & & 545 & & & 240 & & \\
\hline
\end{tabular}

$\mathrm{df}=$ degrees of freedom; $\mathrm{F}=\mathrm{F}$-statistic; $\mathrm{p}=p$-value; $*=$ interaction.

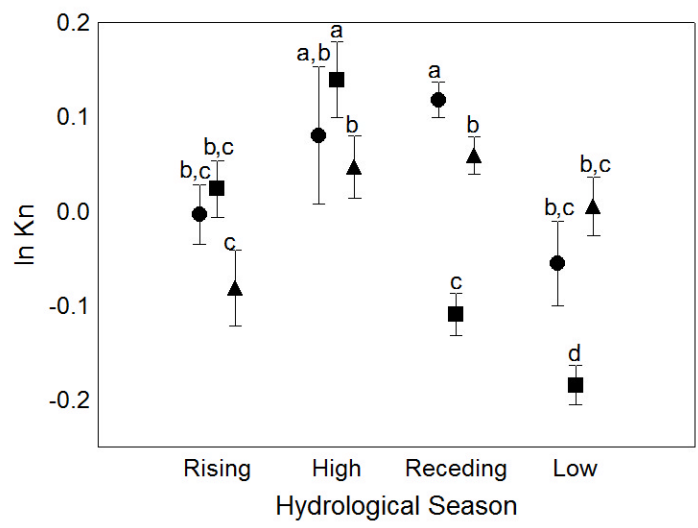

Figure 2. Temporal variation of the condition factor for Colossoma macropomum in the four seasons of the hydrologic cycle: rising, high water, receding and low water for the years 2004 (circle), 2005 (square) and 2006 (triangle). (Different letters imply statistically different means).

and receding and low water seasons of 2005, the year of the drought (Figure 2).

The pattern for M. duriventre was similar, and even more striking: the lowest values of the condition factor occurred as the lakes were shrinking during the drought of 2005 , and there was a sharp recovery in the post-drought year of 2006 during low water (Figure 3). However, the

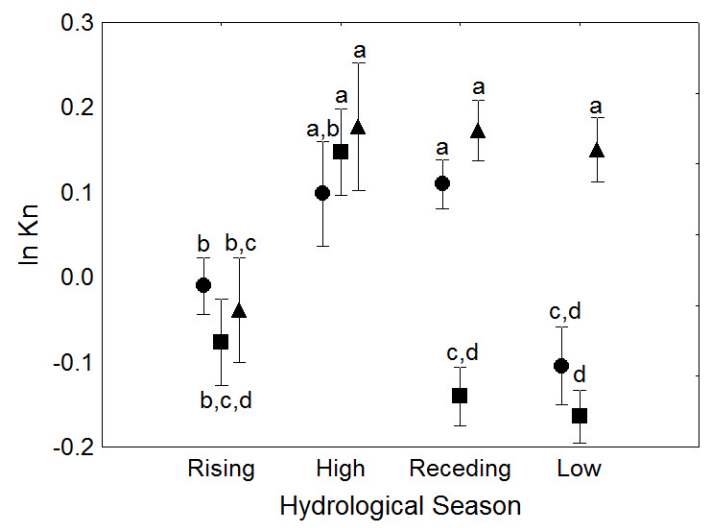

Figure 3. Temporal variation of the condition factor for Mylossoma duriventre in the four seasons of the hydrologic cycle: rising, high water, receding and low water for the years 2004 (circle), 2005 (square) and 2006 (triangle). (Different letters imply statistically different means).

condition factor for this species was also low during the low water period of 2004, before the drought.

In contrast to the patterns for the two omnivorous species, the two piranha species maintained similar values for the condition factor during and after the drought (2005 and 2006, Figures 4 and 5). Serrasalmus spilopleura exhibited its lowest values, with high variability, during high and 
receding water during the pre-drought year of 2004, but showed no changes associated with the drought in 2005 or the subsequent year (Table 3, Figure 4). There were no significant variations in the condition factor for $S$. elongatus among years or seasons of the hydrologic cycle (Figure 5).

Besides, the interaction effects between intra- and inter-annual factors detected for C. macropomum and $M$. duriventre exhibited opposite patterns in comparison with $S$. spilopleura. The first two omnivorous species showed a marked reduction of the condition factor during the extreme drought of 2005 (Figures 2 and 3), while the lowest values for $S$. spilopleura were obtained during the pre-drought year of 2004 (Figure 4).

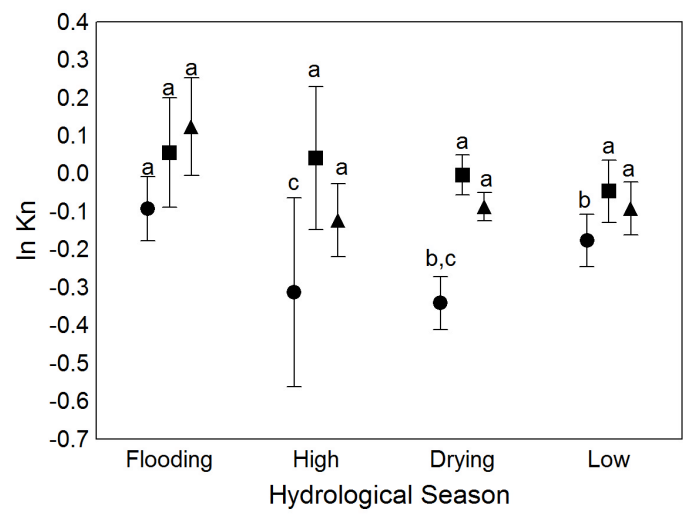

Figure 4. Temporal variation of the condition factor for Serrasalmus spilopleura in the four seasons of the hydrologic cycle: rising, high water, receding and low water for the years 2004 (circle), 2005 (square) and 2006 (triangle). (Different letters imply statistically different means).

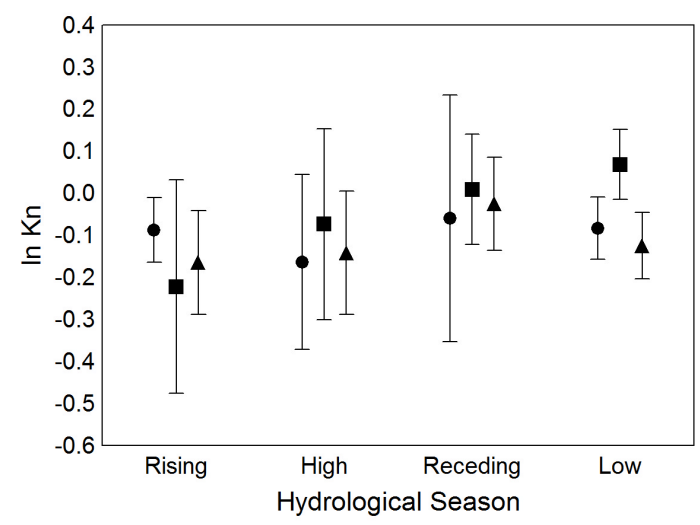

Figure 5. Temporal variation of the condition factor for $S$. elongatus in the four seasons of the hydrologic cycle: rising, high water, receding and low water for the years 2004 (circle), 2005 (square) and 2006 (triangle).

\section{Discussion}

Our results suggest that the intensity of an anomalous drought can result in perceptible effects on Amazonian fish that are related to their trophic niche. The general pattern of intra-seasonal condition factor for the two omnivores reflects their life histories, particularly their feeding strategies. Both tambaqui and pacú-manteiga normally exhibit ontogenetic and seasonal changes in their feeding preferences (Honda, 1974; Costa et al., 1999; Soares et al., 2007), which are pre-adapted to correlate with a predictable and monomodal hydrologic cycle. These species enter the flooded forest around floodplain lakes after breeding in order to feed and shelter as the water rises each year (Honda, 1974; Fernandes, 1997; Araújo-Lima and Ruffino, 2003). The importance of allochthonous items, as fruits and seeds, originated from the flooded forest in the diet of $C$. macropomum and $M$. duriventre is well-known (Araújo-Lima and Goulding, 1998; Claro-Junior et al., 2004).

Thus, their condition factor is high while they are feeding in the forest and their fat stores may carry them through most of the short low water season, and then they reproduce during rising water (Araújo-Lima and Ruffino, 2003). Both of these fish populations exhibited much lower mean condition factors during the receding and low water seasons during the year of the drought, when the flooded forest would have been available to them for less time than usual. This may be an indication that increasing drought duration and frequency, predicted as a result of global climate change (Malhi et al., 2008; Marengo et al., 2008; Melack and Coe, 2013), fish species with high dependency of flooded habitats could be more affected. Thus, extreme droughts could push them beyond their adaptive limits and thus have negative, and potentially catastrophic, impacts on their population biology.

Serrasalmus spilopleura is predominantly piscivorous, but also has been found to eat insects (Costa et al., 2005) and varies its diet over the course of the year (Raposo and Gurgel, 2003). Whereas the diet of S. elongatus is more constant along the year, being composed mainly by fish fins and scales (Nico and Taphorn, 1988). These two piranhas exhibited no changes in condition factors that could be attributed to the extreme drought that happened in 2005. Low water periods, if not extremely long, may favor this trophic level, since as water volume declines the relative density of potential prey increases, which increases the encounter rate between predators and their prey (Winemiller and Jepsen, 1998). This phenomenon acts as a buffer against loss of fitness because unlike the omnivores, their food source is still available to them. On this basis one might predict that predators would fare better, at least in the short run, during climate change. The differences between S. spilopleura and S. elongatus could be associated with the habitat availability. Sazima and Zamprogno (1985) stated that young S. spilopleura use the floating meadows of Eichornia crassipes as shelter and foraging place, and larger juveniles also can be found in open water areas of lakes. We suggest that the complete 
disappearance of floating meadows during the extreme drought of 2005 was more critical for $S$. spilopleura than for S. elongatus.

Obviously, the effects of extreme events of flood and drought would differ among species as well as among trophic levels. Some authors have proposed that the present dominance of omnivorous species within the Amazon Basin may be an evolutionary response to the large diversity of food items and to the seasonality of their abundance and availability (Lowe-McConnell, 1999; Mérona and Rankin-de-Mérona, 2004; Blanchette et al., 2014). An extreme drought could result in a severe deterioration of the water quality, with high temperature and low dissolved oxygen, which would in turn have negative consequences for the quality of their food sources. For instance, it has been suggested that in addition to feeding on abundant $\mathrm{C} 4$ autotrophic sources (Martinelli et al., 1994), Amazonian fish would prefer to exploit C3 sources such as phytoplankton, that are easier to absorb (Forsberg et al., 1993; Mortillaro et al., 2015), but these sources have a tendency to become very scarce during extreme droughts. Both the timing and duration of extreme climatic events are therefore likely to have profound effects on life history strategies of floodplain fish (Ficke et al., 2007). Some wild species, such as the bird Parus major (Charmantier et al., 2008) have been shown to have enough phenotypic plasticity to withstand a limited degree of climatic change by shifting the timing of their life history events, but the degree that this is true, and for which species, can only be determined after the climate has changed, which may well be too late to preserve them.

\section{Acknowledgements}

Financial support of this research was provided by FINEP (PIATAM Project) and INCT ADAPTA. CECF also thanks to CNPq (grants number 302430/2012). Laboratory and logistic support also was provided by UFAM. We acknowledge Jansen Zuanon for help with fish identification.

\section{References}

ALMEIDA-VAL, V.M. and VAL, A.L., 1990. Adaptação bioquímica em peixes da Amazônia. Ciencia Hoje, vol. 11, pp. 62-67.

ARAÚJO-LIMA, C.A.R.M. and GOULDING, M., 1998. So fruitful a fish: ecology, conservation and aquaculture of the Amazon's tambaqui. New York: Columbia University Press.

ARAÚJO-LIMA, C.A.R.M. and RUFFINO, M.L., 2003. Migratory fishes of the Brazilian Amazon. In: J. CAROLSFELD, B. HARVEY, C. ROSS and BAER, A. eds. Migratory Fishes of South America: Biology, Fisheries and Conservation Status. Canada: The World Bank. pp. 223-302.

BITTENCOURT, M.M. and AMADIO, S.A., 2007. Proposta para identificação rápida dos períodos hidrológicos em áreas de várzea do rio Solimões-Amazonas nas proximidades de Manaus. Acta Amazonica, vol. 37, no. 2, pp. 303-308. http://dx.doi.org/10.1590/ S0044-59672007000200019.
BLANCHETTE, M.L., DAVIS, A.M., JARDINE, T.D. and PEARSON, G., 2014. Omnivory and opportunism characterize food webs in a large dry-tropics river system. Freshwater Science, vol. 3, no. 1, pp. 142-158. http://dx.doi.org/10.1086/674632.

CAMPOS, C.P., COSTA SOUSA, R.G., CATARINO, M.F., ALBUQUERQUE COSTA, G. and FREITAS, C.E.C., 2015. Population dynamics and stock assessment of Colossoma macropomum caught in the Manacapuru Make system (Amazon Basin, Brazil). Fisheries Management and Ecology, vol. 22, no. 5, pp. 400-406. http://dx.doi.org/10.1111/fme.12139.

CHARMANTIER, A., MCCLEERY, R.H., COLE, L.R., PERRINS, C., KRUUK, L.E.B. and SHELDON, B.C., 2008. Adaptive phenotypic plasticity in response to climate change in a wild bird population. Science, vol. 320, no. 5877, pp. 800-803. http://dx.doi. org/10.1126/science.1157174. PMid: 18467590.

CLARO-JUNIOR, L., FERREIRA, E.G., ZUANON, J.A. and ARAÚJO-LIMA, C.A.R.M., 2004. O efeito da floresta alagada na alimentação de três espécies de peixes onívoros em lagos de várzea da Amazônia Central, Brasil. Acta Amazonica, vol. 34, no. 1, pp. 133-137. http://dx.doi.org/10.1590/S0044-59672004000100018.

CORREA, S.B. and WINEMILLER, K.O., 2014. Niche partitioning among frugivorous fishes in response to fluctuating resources in the Amazonian floodplain Forest. Ecology, vol. 95, no. 1, pp. 210-224. http://dx.doi.org/10.1890/13-0393.1. PMid:24649660.

COSTA, A.C., SALVADOR JUNIOR, L.F., DOMINGOS, F.F.T. and FONSECA, M.L., 2005. Alimentação da pirambeba Serrasalmus spilopleura Kner, 1858 (Characidae; Serrasalmidae) em um reservatório do Sudeste Brasileiro. Acta Scientiarum Biological Series, vol. 27, pp. 365-369.

COSTA, L.R.F.D., BARTHEM, R.B. and CORREA, M.A.V., 1999. Manejo da pesca do tambaqui nos lagos de varzea da RDSM. In: H.L. QUEIROZ and W.G.R. CRAMPTON, eds. Estratégias para manejo de recursos pesqueiros em Mamirauá. Tefé: Sociedade Civil Mamirauá, CNPq, pp. 142-158.

CREN, E.D.L., 1951. The length-weight relationship and seasonal cycle in gonad weight and condition in the perch (Perca fluviatilis). Journal of Animal Ecology, vol. 20, no. 2, pp. 201-219. http:// dx.doi.org/10.2307/1540.

FERNANDES, C.C., 1997. Lateral migrations of fishes in Amazon floodplains. Ecology Freshwater Fish, vol. 2, no. 1, pp. 36-44. http://dx.doi.org/10.1111/j.1600-0633.1997.tb00140.x.

FICKE, A.D., MYRICK, C.S. and HANSEN, L.J., 2007. Potential impacts of climate changes on freshwater fisheries. Reviews in Fish Biology and Fisheries, vol. 17, no. 4, pp. 581-613. http:// dx.doi.org/10.1007/s11160-007-9059-5.

FORSBERG, B.R., ARAÚJO-LIMA, C.A.R.M., MARTINELLI, L.A., VICTORIA, R.L. and BONASSI, J.A., 1993. Autotrophic carbon sources for fish of the Central Amazon. Ecology, vol. 74, no. 3, pp. 643-652. http://dx.doi.org/10.2307/1940793.

FREITAS, C.E.C., NASCIMENTO, F.A. and SIQUEIRA-SOUZA, F.K., 2007. Levantamento do estado de explotação dos estoques de Curimatã, Jaraqui, Surubim e Tambaqui. In: M.L. Ruffino, ed. O setor pesqueiro na Amazônia: análise da situação atual e tendências de desenvolvimento da indústria da pesca. Brasília: Provárzea IBAMA, pp. 77-101

FREITAS, C.E.C., SIQUEIRA-SOUZA, F.K., HUMSTON, R. and HURD, L.E., 2013. An initial assessment of drought sensitivity 
in Amazonian fish communities. Hydrobiologia, vol. 705, no. 1, pp. 159-171. http://dx.doi.org/10.1007/s10750-012-1394-4.

GOULDING, M. and CARVALHO, M.L., 1982. Life history and management of the tambaqui (Colossoma macropomum, Characidae): an important Amazonian food fish. Revista Brasileira de Zoologia, vol. 1, no. 2, pp. 107-133. http://dx.doi.org/10.1590/ S0101-81751982000200001.

GOULDING, M., 1980. The fishes and the forest: explorations in Amazonian natural history. Los Angeles: University of California Press.

GRANADO-LORENCIO, C., LIMA, C.R.M.A. and LOBÓNCERVIÁ, J., 2005. Abundance-distribution relationship in fish assembly of Amazonas floodplain lakes. Ecography, vol. 28, no. 4, pp. 515-520. http://dx.doi.org/10.1111/j.0906-7590.2005.04176.x.

HONDA, E.M.S., 1974. Contribuição ao conhecimento da biologia de peixes do Amazonas. II. Alimentação do tambaqui, Colossoma bidens. Acta Amazonica, vol. 4, pp. 47-53.

HURD, L.E., SOUSA, R.G.C., SIQUEIRA-SOUZA, F.K., COOPER, G.J., KAHN, J.R. and FREITAS, C.E.C., 2016. Amazon floodplain fish communities: habitat connectivity and conservation in a rapidly deteriorating environment. Biological Conservation, vol. 195, pp. 118-127. http://dx.doi.org/10.1016/j. biocon.2016.01.005.

ISAAC, V.J. and RUFFINO, M.L., 1996. Population dynamics of tambaqui, Colossoma macropomum Cuvier, in the lower Amazon, Brazil. Fisheries Management and Ecology, vol. 3, no. 4, pp. 315-333. http://dx.doi.org/10.1046/j.1365-2400.1996.d01-154.x.

JUNK, W.J., BAYLEY, P.B. and SPARKS, R.E., 1989. The flood pulse concept in river-floodplain system. In: D.P. Dodge, ed. Proceedings of the International Large River Symposium - LARS, 1989, Honey Harbour. Ottawa: Canadian journal of fisheries and aquatic sciences, no. 106, pp. 110-127.

LIMA, A.C. and ARAÚJO-LIMA, C.A.R.M., 2004. The distributions of larval and juvenile fishes in Amazonian rivers of different nutrient status. Freshwater Biology, vol. 49, no. 6, pp. 787-800. http://dx.doi.org/10.1111/j.1365-2427.2004.01228.x.

LOWE-MCCONNELL, R., 1999. Estudos ecológicos em comunidades de peixes tropicais. São Paulo: Editora da Universidade de São Paulo.

MALHI, Y., ROBERTS, J.T., BETTS, R.A., KILLEEN, T.J., LI, W. and NOBRE, C.A., 2008. Climate change, deforestation, and the fate of the Amazon. Science, vol. 319, no. 5860, pp. 169-172. PMid:18048654. http://dx.doi.org/10.1126/science.1146961.

MARENGO, J.A., 1992. Interannual variability of surface climate in the Amazon basin. International Journal of Climatology, vol. 12, no. 8, pp. 853-863. http://dx.doi.org/10.1002/joc.3370120808.

MARENGO, J.A., BORMA, L.S., RODRIGUEZ, D.A., PINHO, P., SOARES, W.R. and ALVES, L.M., 2013. Recent extreme of drought and flooding in Amazonia: vulnerabilities and human adaptation. American Journal of Climate Change, vol. 2, no. 02, pp. 87-96. http://dx.doi.org/10.4236/ajcc.2013.22009.

MARENGO, J.A., NOBRE, C.A., TOMASELLA, J., OYAMA, M.D., OLIVEIRA, G.S., OLIVEIRA, R., CAMARGO, H., ALVES, L.M. and BROWN, I.F., 2008. The drought of Amazonia in 2005. Journal of Climate, vol. 21, no. 3, pp. 495-516. http:// dx.doi.org/10.1175/2007JCLI1600.1.
MARTINELLI, L.A., VICTORIA, R.L., FORSBERG, B.R. and RICHEY, J.E., 1994. Isotopic composition of major carbon reservoirs in the Amazon floodplain. International Journal of Ecology and Environmental Sciences, vol. 20, pp. 31-46.

MELACK, J.M. and COE, M.T., 2013. Climate change and the floodplain lakes of the Amazon Basin. In: C.R. GOLDMAN, M. KUMAGAI and R.D. ROBARTS, eds. Climatic change and global warming of inland waters: impacts and mitigation for ecosystems and societies. New York: John Wiley \& Sons, pp. 295-310.

MÉRONA, B. and RANKIN-DE-MÉRONA, J., 2004. Food resource partitioning in a fish community of the central Amazon floodplain. Neotropical Ichthyology, vol. 2, no. 2, pp. 75-84. http:// dx.doi.org/10.1590/S1679-62252004000200004.

MORTILLARO, J.M., POUILLY, M., WACH, M., FREITAS, C.E.C., ABRIL, G. and MEZIANE, T., 2015. Trophic opportunism of central Amazon floodplain fish. Freshwater Biology, vol. 60 , no. 8, pp. 1659-1670. http://dx.doi.org/10.1111/fwb.12598.

MYERS, J.H., 1990. Population cycles of western tent caterpillars: experimental introductions and synchrony of fluctuations. Ecology, vol. 71, no. 3, pp. 986-995. http://dx.doi.org/10.2307/1937367.

NICO, L.G. and TAPHORN, D.C., 1988. Food habits of piranhas in the Low Llanos of Venezuela. Biotropica, vol. 20, no. 4, pp. 311-321. http://dx.doi.org/10.2307/2388321.

NOVERAS, J., YAMAMOTO, K.C. and FREITAS, C.E.C., 2010. Use of the flooded forest by fish assemblages in lakes of the National Park of Anavilhanas (Amazonas, Brazil). Acta Amazonica, vol. 42, pp. 567-572.

PHILLIPS, O.L., ARAGÃO, L.E., LEWIS, S.L., FISHER, J.B., LLOYD, J., LÓPEZ-GONZÁLEZ, G., MALHI, Y., MONTEAGUDO, A., PEACOCK, J., QUESADA, C.A., VAN DER HEIJDEN, G., ALMEIDA, S., AMARAL, I., ARROYO, L., AYMARD, G., BAKER, T.R., BÁNKI, O., BLANC, L., BONAL, D., BRANDO, P., CHAVE, J., DE OLIVEIRA, A.C., CARDOZO, N.D., CZIMCZIK, C.I., FELDPAUSCH, T.R., FREITAS, M.A., GLOOR, E., HIGUCHI, N., JIMÉNEZ, E., LLOYD, G., MEIR, P., MENDOZA, C., MOREL, A., NEILL, D.A., NEPSTAD, D., PATIÑO, S., PEÑUELA, M.C., PRIETO, A., RAMÍREZ, F., SCHWARZ, M., SILVA, J., SILVEIRA, M., THOMAS, A.S., STEEGE, H.T., STROPP, J., VÁSQUEZ, R., ZELAZOWSKI, P., ALVAREZ DÁVILA, E., ANDELMAN, S., ANDRADE, A., CHAO, K.J., ERWIN, T., DI FIORE, A., HONORIO C, E., KEELING, H., KILLEEN, T.J., LAURANCE, W.F., PEÑA CRUZ, A., PITMAN, N.C., NÚÑEZ VARGAS, P., RAMÍREZ-ANGULO, H., RUDAS, A., SALAMÃO, R., SILVA, N., TERBORGH, J. and TORRES-LEZAMA, A., 2009. Drought sensitivity of the Amazon rainforest. Science, vol. 323, no. 5919, pp. 1344-1347. http://dx.doi.org/10.1126/science.1164033. PMid:19265020.

RAPOSO, R.M.G. and GURGEL, H.C.B., 2003. Variação da alimentação natural de Serrasalmus spilopleura Kner, 1860 (Pisces, Serrasalmidae) em função do ciclo lunar e das estações do ano na lagoa de Extremoz, Rio Grande do Norte, Brasil. Acta Scientiarum-Animal Series, vol. 25, pp. 267-272.

SAINT-PAUL, U. and SOARES, M.G.M., 1987. Diurnal distribution and behavioral responses of fishes to extreme hypoxia in an Amazon floodplain lake. Environmental Biology of Fishes, vol. 2, no. 2, pp. 91-104. http://dx.doi.org/10.1007/BF00005289.

SAINT-PAUL, U., ZUANON, J.A., CORREA, M.A.M., GARCIA, M., FABRÉ, N.N., BERGER, U. and JUNK, W.J., 2000. Fish communities in central Amazonian white- and blackwater 
floodplains. Environmental Biology of Fishes, vol. 57, no. 3, pp. 235-250. http://dx.doi.org/10.1023/A:1007699130333.

SAZIMA, I. and ZAMPROGNO, C., 1985. Use of water hyacinths as shelter, foraging place, and transport by young piranhas, Serrasalmus spilopleura. Environmental Biology of Fishes, vol. 12, no. 3, pp. 237-240. http://dx.doi.org/10.1007/BF00005154.

SOARES, M.G.M., COSTA, E.L., SIQUEIRA-SOUZA, F.K., ANJOS, H.D.B., YAMAMOTO, K.C. and FREITAS, C.E.C., 2007. Peixes de lagos do médio rio Solimões. Manaus: EDUA.

SOUSA, R.G.C. and FREITAS, C.E.C., 2008. The influence of flood pulse on fish communities of floodplain canals in the Middle
Solimões River, Brazil. Neotropical Ichthyology, vol. 6, no. 2, pp. 249-255. http://dx.doi.org/10.1590/S1679-62252008000200013.

STATSOFT INC, 2009. STATISTICA: data analysis software system. Version 9.0 [software]. Available from: www.statsoft.com

VAL, A.L., SILVA, M.N.P. and ALMEIDA-VAL, V.M.F., 1998. Hypoxia adaptation in fish of the Amazon: A never-ending task. South African Journal of Zoology, vol. 33, no. 2, pp. 107-114. http://dx.doi.org/10.1080/02541858.1998.11448459.

WINEMILLER, K.O. and JEPSEN, D.B., 1998. Effects of seasonality and fish movement on tropical river food webs. Journal of Fish Biology, vol. 53, suppl. A, pp. 267-296. http:// dx.doi.org/10.1111/j.1095-8649.1998.tb01032.x. 